\title{
PROJEKTPEDAGÓGIA PROJEKTMENEDZSER SZEMMEL
}

\author{
PÁlVÖLGYI LAJOS \\ a Project Management Institute Magyar Tagozatának \\ alelnöke \\ palvolgyi.lajos@pmi.hu
}

A napokban került a kezembe M. Nádasi Mária: Projektoktatás - Elmélet és gyakorlat címü kitünő munkája, melynek célja a projektoktatással kapcsolatos elméleti és gyakorlati ismeretek bemutatása. A kötet kapcsán érdekes kérdések merülnek fel a pedagógia és a projektmenedzsment kapcsolatáról. Talán nem is gondoltuk volna, hogy a „projekt” kifejezés használata a pedagógiában már több mint száz évvel ezelőtt megjelent. Gyökerei a csoportmunka és az önállóság biztosításának pedagógiai módszereire vezethetők vissza. A projektoktatás gondolatát egyre bővülő tartalommal reformpedagógiai irányzatok is átvették, és a számos nyugati példa mellett magyarországi kezdeményezések is megjelentek a huszadik században.

A projektmenedzser számára talán kicsit meglepő, hogy a projektoktatás a pedagógiában nem a projektmenedzsment oktatását jelenti, hanem azt, hogy miként alkalmazhatók projektszerü feladatok az oktatásban. Ezzel újszerü, és ami még fontosabb, életszerü pedagógiai helyzetek jönnek létre. Nem csoda, hogy a módszer egyre ismertebbé válik. A pedagógusok továbbképzését például a Bécsi Pedagógiai Intézetben a Projektcentrum végzi; és segíti tanácsokkal, könyv- és videotárral, szakértők címjegyzékével a projektoktatásra vállalkozó tanárokat. Magyarországon pedig 1998-ban Kecskeméten létrejött a Projektpedagógiai Társaság, amely egyebek mellett rendszeres konferenciákat szervez a témában. ${ }^{1}$

Mint a kötetből megtudjuk, a projektpedagógia módszere „valamely komplex téma feldolgozását jelenti, amelynek során a téma meghatározása, a munkamenet megtervezése és megszervezése, a témával való foglalkozás, a munka eredményeinek létrehozása és bemutatása a tanulók valódi önálló (egyéni, páros, csoportos) tevékenységén alapul" (18. o.). Jellemzője, hogy a tanulók problémafelvetéséből indul ki; valóságos helyzethez kapcsolódik; kidolgozása hosszabb időtartamra nyúlik el; interdiszciplináris jellegü; a pedagógusok és a tanulók egyenrangú, de különböző kompetenciájú partnerekként dolgoznak együtt; a tanulók önállóan döntenek, és felelősek saját döntéseikért; a tanulók közötti kapcsolatok erősek, kommunikatívak; és a pedagógus stimuláló, szervező, tanácsadó szerepbe vonul vissza. A munka egyebek között áttekinti a projekteken alapuló oktatás céljait, tartamát, a tanulási

\footnotetext{
${ }^{1}$ A társaság honlapja: URL: http://www.ketif.hu/pedagogiai_projekt Letöltés ideje: 2015. 01. 12.
} 
folyamat sajátosságait, a szervezeti formákat, a módszereket, a tárgyi feltételeket, a személyközi kapcsolatok alakulását és az értékelés kérdéseit (20-48. o.). A második részben a különböző oktatási szintekhez kapcsolódó érdekes projektpedagógiai kezdeményezések leírásait találjuk (49-87.o.).

Egy igazán izgalmas és fontos területet ismerünk meg a pedagógia és a projektmenedzsment határán. Hiszen az, hogy lehetőleg mindenki már fiatal korban érdemi tapasztalatokat szerezzen projektek tervezésében és végrehajtásában, megérezze a kezdeményezés, az önálló munka, az új létrehozásának, és a többiekkel történő együttműködésnek az örömét, nyilvánvalóan lényeges hozzájárulás ahhoz, hogy később felnőttként sikeres legyen. A bemutatott példákat projektmenedzsment-szakmai szempontból olvasva azonban úgy tünik, a leírt pedagógiai kezdeményezésekben a projektmenedzsment módszereiből vélhetően jóval kevesebb kerül alkalmazásra annál, mint ami szükséges és lehetséges lenne. Fontos alapelvek, módszerek nem jelennek meg a tudatos alkalmazás szintjén, más módszerek pedig igencsak sajátos formában bukkannak fel. Ilyenek például a „nálunk még csak ritkán használt" munkakártyák és a logikai térkép (32. o.).

A projektmenedzsment szakmai szempontok következetesebb érvényesítésével ezek a kezdeményezések bizonyára még hasznosabbak és sikeresebbek lennének. Némi egyszerüsítéssel mondhatjuk, hogy a projektmenedzsment középpontjában a korszerü munkaszervezés áll. Nem megfelelő tervezés és előkészítés esetén a projektpedagógiai kezdeményezések viszont épp azt demonstrálhatják, hogy a rossz munkaszervezés káoszhoz vezet. A projektben ugyanis olyan újszerü feladat végrehajtásáról van szó, amelynek során általában felbomlik a munkamegosztás és a szerepek szokásos rendje. Ha ezek helyébe új struktúra nem lép, az zürzavart eredményez. és a résztvevők nem találják helyüket. A pedagógusnak tehát egy kicsit projektvezetőnek is kell lennie ahhoz, hogy a projektpedagógia pozitív hatása érvényre juthasson, hogy a közös projektsiker motiváló élményét valóban megismerhessék.

Mi kell ehhez? Néhány fontosabb példa a teljesség igénye nélkül: világos megállapodás a projekt céljáról, és ennek rögzítése (mit kívánunk elérni, létrehozni, miért jó ez bárkinek, mikor sikeres a projekt); továbbá annak közös tisztázása, hogy milyen közbülső feladatokat kell elvégezni a cél érdekében; kinek mi lesz a konkrét szerepe; melyik feladat hogyan függ a másiktól; milyen sorrendben hajtsuk végre a feladatokat, ill. mi az, ami párhuzamosan folyhat; milyen anyagokra, eszközökre, esetleg külső segítségre van szükség; mik lesznek a határidők; merülnek-e fel költségek; menetközben miként ellenőrizzük, hogy megfelelöen haladunk-e; hogyan kezeljük, ha később valamilyen akadály vagy változtatási igény merülne fel; miként zárjuk a projektet, értékelve az eredményeket és megbeszélve a tanulságokat; hogyan hasznosul az eredmény stb.

A fenti szempontokat és a kapcsolódó eszközöket, módszereket részletesen tárgyalja a magyar nyelven elérhető szakirodalom, amely hasznos segítséget nyújt- 
hat a projektpedagógiai kezdeményezések vezetőinek is (lásd még Verzuh, 2006; Projektmenedzsment, 2006). A projektmenedzsment, mint szakma egyébként nemcsak a projektpedagógiának adhatna sokat, de hozzáértő alkalmazása a pedagógia és az oktatás más területein is nagyon hasznos lehet.

Mivel napjainkban Magyarországon az iskolák egyre nagyobb szakmai autonómiával rendelkeznek, a projektoktatás alkalmazásának egyre kevesebb objektív akadálya van: a dolog valójában ma már elsősorban a pedagógusok ismeretén, hozzáállásán, akaratán múlik.

Lehetőség nyílik tehát arra, hogy a projektmódszer alkalmazása a jövőben gyorsabban és hatékonyabban terjedjen. Úgy gondolom, hogy ezt elsősorban a pedagógusképzés és -továbbképzés területén kellene erösíteni, nem utolsósorban a projektmenedzsment ismereteket közvetítő szakmai képzés terjesztésével, javításával is. (A módszer akkor lehet ugyanis igazán sikeres, ha a modern pedagógiai koncepció korszerü projektmenedzsmenttel párosul.) Ezt egészítenék ki a különböző iskolatípusokban folyó jól előkészített kezdeményezések, kísérletek; valamint ezek tapasztalatainak dokumentálása és szisztematikus feldolgozása. A projektpedagógia további fejlesztésében a projektmenedzsment hazai szakmai egyesületei is nyilvánvalóan értékes szerepet vállalhatnának ${ }^{2}$.

Az, hogy a projektkultúra hol milyen szinten áll, lényegesen befolyásolja intézmények, vállalatok, városok, régiók, sőt országok versenyképességét. Megújuló, fejlődő gazdaság manapság nem létezhet eredményes projektek nélkül. A projektkultúra az egyén számára azt jelenti, hogy jelentős, újszerü és komplex feladatok megoldásában sikeres lehet. Nádasi Mária könyve tehát társadalmi-gazdasági szempontból alapvető kérdést érint. Biztosra vehető, hogy a projektpedagógia a XXI. század pedagógiájának egyik fontos fejezete lesz. Remélhetőleg sok további hasonlóan izgalmas és hasznos beszámoló követi ezt az alapvetést. A könyv az első megjelenés óta több kiadást is megért.

\section{Irodalom}

Verzuh, E. (2006): Projektmenedzsment. HVG Könyvek, Budapest.

Projektmenedzsment útmutató (PMBOK® Guide). Akadémiai Kiadó, Budapest, 2006.

M. Nádasi Mária: Projektoktatás - Elmélet és gyakorlat. Gondolat Kiadói Kör, Budapest, 2003, 92 oldal

\footnotetext{
${ }^{2}$ Project Management Institute, Magyar Tagozat URL: www.pmi.hu Letöltés ideje: 2014. 12. 11.; Fővállalkozók Maqyarországi Szövetsége (www.fovosz.hu), Magyar Projektmenedzsment Szövetség URL: www.pmsz.hu Letöltés ideje: 2014. 12. 11.
} 